ISSN: 1829-6750 Inovasi Kurikulum, Februari 2009, Thn. 6. Vol 6 Nomor: 1

\title{
ANALISIS RELEVANSI DESAIN KURIKULUM PELATIHAN GURU PAI MTs DENGAN KEBUTUHAN KOMPETENSI GURU DI LAPANGAN
}

\section{Adimin Diens, S.Ag, M.Pd}

Abstrak. Lemahnya efektivitas pembelajaran Pendidikan Agama Islam menjadi permasalahan yang cukup serius. Selama ini telah terjadi anggapan negatif terhadap pelaksanaan pendidikan agama di sekolah. Persoalan kompetensi guru madrasah merupakan permasalahan yang dihadapi hampir seluruh madrasah di tanah air tidak terkecuali Madrasah Tsanawiyah dan secara spesifik guru Pendidikan Agama Islam. Upaya peningkatan kompetensi guru Pendidikan Agama Islam pada madrasah dapat dilakukan melalui jalur pendidikan prajabatan (preservice training) maupun pendidikan dalam jabatan (inservice training). Secara umum pendidikan dan pelatihan ini di samping untuk meningkatkan kompetensi sumber daya manusia, juga diarahkan untuk menjawab kebutuhan-kebutuhan, baik tuntutan masyarakat maupun keniscayaan global. Program-program pelatihan yang ditawarkan paling tidak dapat mengakomodasi standar-standar kompetensi minimal sehingga terdapat relevansi antara kebutuhan-kebutuhan di lapangan dan program pendidikan dan pelatihan. Untuk itu Balai Diklat Keagamaan dalam mengelola dan menyelenggarakan pendidikan dan pelatihan harus sesuai dengan kebutuhan unit pelaksana teknis di lingkungan Departemen Agama. Untuk kepentingan tersebut, kurikulum pelatihan Balai Diklat Keagamaan semestinya memiliki relevansi dengan kebutuhan lapangan. Kesesuaian antara kurikulum pelatihan dengan kebutuhan unit - unit pelaksana teknis di lapangan akan memberikan beberapa keuntungan diantaranya pertama, hasil pelatihan akan lebih bermakna bagi peserta pelatihannya karena kurikulum diklat didesain mengacu pada kebutuhan riil yang berhubungan dengan tugas dan fungsi unit pelaksana teknis. Kedua, penyelenggaraan kegiatan pelatihan lebih efektif karena akan lebih memotivasi peserta pelatihan untuk meningkatkan kompetensi sesuai dengan bidang tugasnya. Ketiga, penyelenggaraan pelatihan lebih efesien, karena kurikulum pelatihan dirancang memang untuk memenuhi kebutuhan tertentu.

Kata Kunci : Kurikulum Pelatihan, Relevansi, Kebutuhan Kompetensi 
ISSN: 1829-6750 Inovasi Kurikulum, Februari 2009, Thn. 6. Vol 6 Nomor: 1

\section{A. Pendahuluan}

Madrasah sebagai salah satu satuan pendidikan dalam menjalankan fungsinya menghadapi sejumlah permasalahan diantaranya terkait dengan kinerja guru. Masih banyak guru madrasah yang belum memenuhi persyaratan kualifikasi. Data hasill survey menunjukkan sekitar 60 persen guru madrasah atau 226.000 guru di semua tingkat salah tempat dan berkualifikasi di bawah yang dipersyaratkan. Mereka umumnya guru lulusan Pendidikan Agama Islam (PAI) yang terpaksa mengajar mata pelajaran di luar bidangnya karena ketiadaan guru berbagai mata pelajaran. Lebih ironis lagi ada Iulusan Madrasah Aliyah yang tidak memiliki latar belakang pengetahuan keguruan menjadi guru pada madrasah Tsanawiyah. Menurut Mahfud dan M. Saifuddin (2005:1), guru-guru madrasah saat ini kondisinya masih jauh dari kata profesional.

Seiring dengan tuntutan peningkatan kualitas pendidikan, muncul kebijakan pemerintah Nomor 19 Tahun 2005 tentang Standar Nasional Pendidikan yang disusul dengan lahirnya Peraturan
Menteri Pendidikan Nasional 22, 23 dan 24 tahun 2006 dimana kebijakan ini berimplikasi pada semakin menantangnya peran sekolah/madrasah dan guru. Sekolah/madrasah dan guru tidak hanya sebagai implementator kurikulum melainkan juga menjadi pengembang (developer) kurikulum pada tingkat satuan pendidikan masing-masing. Sekaitan dengan hal tersebut, perlu adanya upaya peningkatan kompetensi guru Pendidikan Agama Islam pada madrasah, diantaranya dapat dilakukan melalui jalur pendidikan prajabatan (preservice training) maupun pendidikan dalam jabatan (inservice training).

Merujuk pada Keputusan Menteri Agama Nomor 345 Tahun 2004 tentang organisasi dan tata kerja Balai Pendidikan dan Pelatihan Keagamaan, salah satu fungsi Balai Diklat keagamaan adalah menyelenggarakan pendidikan dan pelatihan bagi tenaga administrasi dan tenaga teknis keagamaan di lingkungan Departemen Agama, termasuk pelatihan fungsional guru.

Kurikulum Pendidikan dan Pelatihan Guru Pendidikan Agama semestinya dirancang dengan mengacu pada persoalanpersoalan kebutuhan peningkatan 
ISSN: 1829-6750 Inovasi Kurikulum, Februari 2009, Thn. 6. Vol 6 Nomor: 1

kompetensi guru Pendidikan Agama Islam, yakni sebagai tenaga pendidik, tenaga pengajar, tenaga pembimbing dan pelatih sehingga tujuan dan konten kurikulumnya tidak hanya dibatasi pada penguasaan cognitive skills, tapi juga skills yang lainnya.

Tetapi, apakah materi diklat benar benar berbekas sehingga menjadi sebuah penyegaran dan pembentukan kompetensi baru benar-benar bermanfaat bagi alumni diklat ketika mereka kembali ke lapangan?

Dalam tataran berpikir inilah, peneliti ingin melakukan pengkajian terhadap relevansi desain kurikulum pelatihan bagi guru Pendidikan Agama Islam dengan kebutuhan unit pelaksana teknis dalam hal ini adalah Madrasah Tsanawiyah yang selama ini telah digunakan oleh Balai Diklat Keagamaan Manado, Sulawesi Utara. Berdasarkan latar belakang tersebut, dirumuskan masalah penelitian yang menjadi fokus penelitian yaitu bagaimanakah relevansi desain kurikulum pelatihan guru PAI MTs pada Balai Diklat Keagamaan Manado dengan kebutuhan kompetensi guru di lapangan.. Untuk mengarahkan permasalahan ini pada fokusnya, dikemukakan paradigma konseptual sebagai berikut:

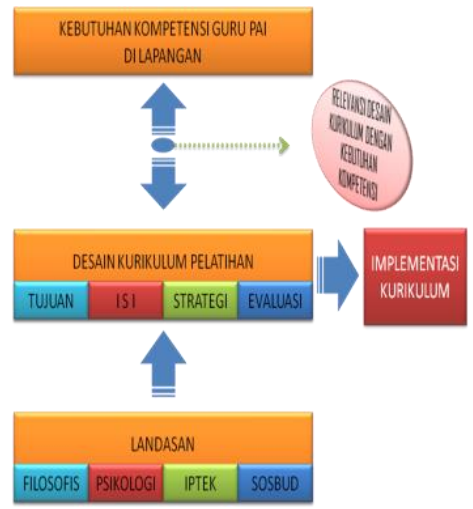

Gambar 1. Paradigma Konseptual Relevansi Desai Kurikulum dengan Kebutuhan Kompetensi Guru

\section{B. Kajian Teori}

\section{Konsep Pengembangan Kurikulum Pelatihan}

\section{Desain Kurikulum Pelatihan}

Pengertian kurikulum dapat dipahami dalam dua perspektif, yaitu perspektif sempit dan luas. Secara sempit kurikulum merujuk kepada istilah curir (pelari) dan (Print,1993:111) curere yang dapat dipahami sebagai jarak yang harus ditempuh seorang pelari. Pengertian tersebut diterapkan dalam dunia pendidikan menjadi 
ISSN: 1829-6750 Inovasi Kurikulum, Februari 2009, Thn. 6. Vol 6 Nomor: 1

sejumlah mata pelajaran (subject) yang harus ditempuh oleh seorang siswa dari awal sampai akhir program pembelajaran untuk memperoleh penghargaan dalam bentuk ijazah. Pengertian ini memberikan indikasi bahwa setiap kurikulum memiliki dua komponen utama, yaitu (1) adanya mata pelajaran yang harus ditempuh oleh siswa dan (2) adanya tujuan utama yaitu untuk mendapatkan penghargaan berupa ijazah.

Pelatihan adalah $\begin{array}{r}\text { upaya } \\ \text { pembelajaran }\end{array}$
yang diselenggarakan oleh organisasi baik pemerintah, maupun lembaga swadaya masyarakat ataupun perusahaan dengan tujuan untuk memenuhi kebutuhan organisasi untuk mencapai tujuannya organisasi. Pengertian ini didasarkan pada defenisi yang dikemukakan oleh Friedman dan Yarbrough (1985) dalam Sudjana (2006:132) bahwa: "Training is a process used by organization to meet their goals. It is called into operation when a discrepancy is perceived between the current situation and a preferred state of affairs".

Defenisi ini juga memberikan pemahaman bahwa sebuah pelatihan dianggap berhasil bila bisa membawa realitas sumber daya manusia saat ini kepada sebuah realitas sumber daya manusia yang seharusnya diinginkan oleh organisasi sehingga peran pelatih pada proses pembelajaran adalah membantu membelajarkan peserta pelatihan agar dapat merubah yang biasanya ditampilkan pada saat ini menjadi perilaku yang seharusnya yang diharapkan oleh lembaga (Sudjana, 2006:1327).

Peraturan Pemerintah Nomor 71
Tahun $1991 \quad$ mengemukakan pengertian yang lebih operasional bahwa pelatihan adalah keseluruhan kegiatan untuk memberikan, memperoleh, meningkatkan serta mengembangkan keterampilan, produktivitas, disiplin kerja dan etos kerja pada tingkat keterampilan tertentu yang pelaksanaannya lebih mengutamakan praktek dari pada teori.

Pada dasarnya kurikulum pelatihan didesain seperti halnya kurikulum pada umumnya yang mencakup empat komponen utama sebagaimana yang dikemukakan oleh Tyler (1949), yaitu: (1) What educational purposes the school seek to attain? (2) What educational experiences can be provided that is likely to attain these 
ISSN: 1829-6750 Inovasi Kurikulum, Februari 2009, Thn. 6. Vol 6 Nomor: 1

purposes? (3) How can these educational experiences be effectively organized? Serta (4) How can we determine whether these purposes are being attained? Jawaban keempat pertanyaan mendasar tersebut yang kemudian lebih dikenal juga dengan istilah anatomi kurikulum, yaitu: (1) tujuan (aims, goals, objective); (2) isi materi (content); (3) kegiatan belajar (learning activities); (4) evaluasi (evaluation) (Zais,1976: 295). Komponen-komponen tersebut dirancang tidak berdiri sendiri melainkan satu sama lain saling terkait dan saling berkesesuaian (relevansi).

Dalam pengembangan kurikulum pelatihan harus memperhatikan sejumlah prinsip pengembangan kurikulum. Prinsip-prinsip tersebut dapat dibedakan dalam dua kategori, yaitu prinsip-prinsip umum dan prinsip khusus. Prinsip umum biasanya digunakan pada pengembangan kurikulum pada umumnya, sementara prinsip khusus bersifat kondisional, berlaku pada tempat dan situasi tertentu. Salah satu prinsip umum pengembangan kurikulum yaitu prinsip relevansi.

\section{Relevansi Kurikulum Pelatih-} an
Pada Oxford Advanced learners's Dictionary of Current English (1982:711) kata "relevansi" merupakan kata sifat dari kata relevancy atau relevance yang dimaknai (closely) conected with what is happening, being discussed, done etc. Dari pengertian ini dapat dipahami bahwa relevansi adalah keterkaitan, keterhubungan dengan apa yang terjadi. Relevansi dalam konteks penelitian dimaknai sebagai kesesuaian, keterkaitan atau keselarasan antara desain kurikulum pelatihan di satu sisi dan kebutuhan-kebutuhan dan tuntutan masyarakat di pihak lain.

Prinsip relevansi dalam pendidikan, mutlak dibutuhkan. Karena salah satu orientasi pendidikan adalah pemenuhan kebutuhan sosial dan kebutuhan individual peserta didik. Dalam proses desain kurikulum, Print (1993:111) menjelaskan. sekurang-kurangnya ada empat hal yang patut diperhatikan dalam kegiatan awal desain kurikulum, yaitu: (1) identifikasi kebutuhan lokal peserta didik, (2) identifikasi kebutuhan orang tua, (3) identifikasi kebutuhan masyarakat, dan (4) identifikasi kebutuhan lokal.

Sementara itu, Hamalik (2006: 41) mengemukakan bahwa kurikulum 
ISSN: 1829-6750 Inovasi Kurikulum, Februari 2009, Thn. 6. Vol 6 Nomor: 1

itu disebut memiliki prinsip relevansi bila sesuai dengan kriteria dunia kerja (vocation), kependudukan (citizenship), hubungan antara orang-orang (personal relationship) , dan aktivitas masyarakat lainnya yang menyangkut budaya, sosial politik.

\section{Analisis Kebutuhan dalam Desain Kurikulum}

Ada beberapa istilah berbeda namun memiliki tujuan yang sama yaitu situation analysis, need assessment, diagnosis of need, sebagai proses untuk mendapatkan informasi yang komprehensif. Hasil analisis ini dibutuhkan dalam perencanaan dan pengembangan isi, strategi dan evaluasi kurikulum.

Satu teknik yang dapat digunakan untuk menentukan analisis situasi termasuk kebutuhan peserta didik terhadap pendidikan dan pelatihan adalah need assessment. Need assessment adalah teknik pengumpulan data untuk menentukan kebutuhan dalam perencanaan program atau kurikulum (Print,1993:111).

Setidaknya ada tiga pendekatan yang dapat digunakan untuk mengidentifikasi pelatihan yaitu:
Pertama, Analisis Kompetensi, ini dilakukan jika kebutuhan pelatihan timbul karena adanya tuntutan kemampuan tertentu dari pegawai, karyawan, guru untuk melakukan suatu pekerjaan atau menduduki sebuah jabatan. Analisis ini dilakukan untuk (1) menguraikan peranan penting yang tercakup dalam sebuah jabatan; menguraikan pekerjaan dalam jabatan itu; (3) menetapkan kemampuan yang harus dimiliki untuk melaksanakan pekerjaan sesuai dengan peran yang tercakup; (4) menentukan pengetahuan dan keterampilan yang diperlukan; dan (5) menetapkan karakteristik peserta. Secara sederhana, melalui pendekatan ini analisis kebutuhan dimulai dengan menghimpun informasi kompetensi apa saja yang seharusnya dimiliki dalam pekerjaan dan jabatan tertentu. Selanjutnya mengidentifikasi pengetahuan, keterampilan dan sikap apa saja yang perlu dimiliki untuk dapat menunjukkan kompetensi itu.

Kedua, Analisis Organisasi. Analisis ini digunakan di samping mengidentifikasi ada tidaknya kebutuhan pelatihan, juga untuk menyediakan informasi dalam 
ISSN: 1829-6750 Inovasi Kurikulum, Februari 2009, Thn. 6. Vol 6 Nomor: 1

penyusunan profil organisasi atau sebuah lembaga pada saat tertentu. Profil ini menjadi dasar lebih lanjut untuk mengidentifikasi faktor-faktor penyebab keadaan yang terjadi dan alternatif penanggulangan yang mungkin dilakukan.

Ketiga, Analisis Kinerja. Dalam organisasi hasil kinerja biasanya diukur berdasarkan kriteria tertentu yang seyogyanya telah ditetapkan sebelumnya. Sedikitnya ada empat faktor utama yang mempengaruhi tinggi rendahnya kinerja pegawai, yaitu (1) faktor pengawai itu sendiri; (2) faktor pekerjaan yang dilakukannya; (3) faktor mekanisme kerja; (4) faktor lingkungan kerja. Analisis kinerja berada pada cakupan faktor-faktor yang mempengaruhi kinerja seorang pegawai.

Pendekatan yang digunakan dalam studi ini adalah analisis kompetensi. Pendekatan ini sesuai dengan upaya peningkatan kompetensi guru dalam melaksanakan tugas jabatan fungsionalnya.

\section{Metode Penelitian}

Penelitian ini menggunakan metode penelitian evaluatif dengan pendekatan kualitatif. Dengan tujuan agar permasalahan bisa dikaji lebih mendalam dan holistik dengan demikian mampu melihat relevansi antara kurikulum pelatihan yang telah desain dengan kebutuhan lapangan dengan kriteria yang digunakan adalah deskripsi tugas pokok jabatan guru.

\section{Hasil Penelitian}

\section{Desain Kurikulum Pelatihan Guru PAI MTs pada Balai Diklat Keagamaan}

Desain kurikulum pelatihan bagi guru Pendidikan Agama Islam Madrasah Tsanawiyah dideskripsikan berdasarkan identifikasi diklat berjenjang yang diselenggarakan oleh Balai Diklat Keagamaan, yaitu diklat jenjang tingkat dasar dan tingkat lanjutan.

Tujuan pendidikan dan pelatihan tingkat dasar adalah untuk meningkatkan pengetahuan keterampilan, kecakapan dan wawasan tugas guru mata pelajaran Pendidikan Agama Islam (Aqidah Akhlak, Fiqih, Qur'an Hadits dan SKI) pada Madrasah Tsanawiyah, serta membentuk kepribadian dan membangun sikap mental yang menjunjung tinggi etika, norma agama dan moral sehingga mereka diharapkan mampu menjadi guru yang 
ISSN: 1829-6750 Inovasi Kurikulum, Februari 2009, Thn. 6. Vol 6 Nomor: 1

profesional, handal dan dapat menjadi teladan baik bagi siswanya maupun bagi masyarakatnya.

Adapun tujuan diklat tingkat lanjutan ini adalah (1) untuk meningkatkan pengetahuan, keterampilan, kecakapan, dan wawasan tugas guru mata pelajaran pada madrasah Tsanawiyah khsususnya di bidang strategi dan evaluasi pembelajaran; (2) Untuk meningkatkan dan memelihara sikap mental, etika dan moral para guru Pendidikan Agama Islam (Aqidah Akhlak, Fiqih, AlQur'an Hadits dan SKI) MTs sebagaimana telah dibentuk pada penyelenggaraan diklat guru mata pelajaran tingkat dasar, serta berupaya meningkatkan kepribadian, komitmen dan sikap keteladanan guru.

2. Tuntutan Kebutuhan Kompetensi Guru PAI MTs

Keberadaan guru Pendidikan Agama Islam demikian penting keberadannya yang multi fungsi,, baik sebagai tenaga pengajar, pelatih, pembimbing, penyuluh bahkan pendidik. Guru Pendidikan Agama Islam dituntut tidak hanya paham ajaran Islam, tetapi ia juga mampu menampilkan ajaran Islam dalam perilaku kesehariannya.

Berikut ini sejumlah tuntutan kemampuan guru PAl bagi peningkatan integritas pribadi keguruan:
a. Tuntutan Peningkatan Ke- mampuan Penguasaan Lan- dasan Kepedidikan
b. Tuntutan Peningkatan Kemampuan Mengembangkan Kuri-kulum dan Silabus
c. Tuntutan Peningkatan Kemam- puan Penguasaan Materi Pelajaran
d. Tuntutan Peningkatan Kemam- puan Mengelola Kegiatan Pembelajaran

e. Tuntutan Peningkatan Kemampuan Pengembangan Strategi Pembelajaran

f. Tuntutan Peningkatan Kemampuan Pengembangan Evaluasi Hasil Belajar

g. Tuntutan Peningkatan Kemampuan Bersosialisasi

3. Relevansi Kurikulum Pelatihan Guru PAI MTs dengan Kompetensi yang Dibutuhkan Guru 
ISSN: 1829-6750 Inovasi Kurikulum, Februari 2009, Thn. 6. Vol 6 Nomor: 1

Muatan kurikulum Diklat Guru PAI MTs tingkat dasar dan tingkat lanjutan dirumuskan berdasarkan tujuan dan standar kompetensi diklat terbagi dalam tiga bagian besar, kelompok mata diklat dasar, kelompok mata diklat inti dan kelompok mata diklat penunjang. Mata Diklat guru PAI MTs ditujukan untuk menjawab tuntutan kebutuhan kompetensi guru PAI di lapangan. Peningkatan kompetensi pedagogik dan profesional menjadi mata diklat inti sementara kompetensi sosial dan personal termuat dalam mata diklat dasar dan penunjang kendatipun tidak maksimal.

Dalam konteks isi atau muatan kurikulum, secara umum dapat menjawab tuntutan kompetensi guru. Kompetensi lain yang belum terjawab melalui mata diklat yang ada adalah (1) kemampuan berupa pengetahuan dan keterampilan pemanfaatan teknologi informasi dan komunikasi (2) kemampuan berkomunikasi efektif, etis dan humanis, (3) kemampuan melakukan refleksi diri untuk menumbuhkan tanggung jawab, kepedulian, keikhlasan dan disiplin bagi guru PAl; (4) kemampuan berkomunikasi dengan teman sejawat dan masyarakat tanpa membedakam struktur sosial, suku agama dan ras.

Dalam hal strategi pembelajaran dalam kurikulum diklat guru PAI MTs tingkat dasar dan tingkat lanjutan, ada tiga kriteria strategi diklat guru PAI MTs yaitu (1) Pendekatan yang digunakan adalah pembelajaran orang dewasa (andragogi); (2) Pemilihan metode yang sesuai dengan karakteristik dan kebutuhan peserta didik dan (3) Penentuan alokasi waktu pada masing-masing diklat.

Metode pembelajaran yang bisa digunakan yaitu metode ekslplorasi pengalaman peserta, metode demonstrasi dan praktek (demonstration and practice) Metode ceramah, tanya jawab dan diskusi kelompok untuk membantu dalam penguasaan pengetahuan terhadap landasan kependidikan dan pendalaman materi. Metode praktek lapangan untuk peningkatan kompetensi dalam hubungannya dengan pengelolan pembelajaran dan pengembangan strategi pembelajaran.

Sementara dari segi alokasi waktu diklat guru PAI MTs tingkat dasar untuk teori $70 \%$, sedangkan alokasi waktu untuk praktek $30 \%$. Alokasi ini belum relevan dengan tuntutan 
ISSN: 1829-6750 Inovasi Kurikulum, Februari 2009, Thn. 6. Vol 6 Nomor: 1

kebutuhan peningkatan kompetensi yang cenderung harus mengedepankan pengalokasian waktu praktik lebih besar daripada teori, paling tidak seimbang.

Pada alokasi diklat guru PAI tingkat lanjutan alokasi waktu praktek mencapai $65 \%$ sementara alokasi waktu untuk pelajaran teori mencapai $35 \%$. Alokasi ini relevan dengan orientasi praktek yang harus dikedepankan.

Evaluasi hasil belajar dalam pendidikan dan pelatihan bertujuan mengetahui tingkat kemampuan penguasaan materi substansi diklat dan untuk menentukan pemberian sertifikat kelulusan. Teknik penilaian yang digunakan adalah (1) tes tertulis, (2) praktek lapangan, (3) penilaian proses diklat berupa pengerjaan tugas, kerja sama dan kedisiplin. Jenisjenis evaluasi tersebut digunakan sesuai dengan karakteristik atau obyek penilaian tersesendiri. Sehingga dalam konteks ini, telah cukup relevan.

\section{E. Pembahasan}

\section{Kesesuaian Tujuan Ku- rikulum Pelatihan dengan}

\section{Tuntutan Kebutuhan Kom- petensi Guru PAI}

Kurikulum diklat PAI MTs pada Balai Diklat Keagamaan Manado menggunakan pendekatan analisis kompetensi, sehingga rumusan tujuannya menjawab tuntutan kebutuhan kompetensi yang dibutuhkan guru PAI di MTs. Blank (1982: 120 -123) mengemukakan " the objective indicates what materials students will need in learning the task (coins dan tubes) as well as the materials needed in testing the student", sehingga perumusan tujuan pelatihan dilakukan setelah melakukan identifikasi dan deskripsi pekerjaan, identifikasi persyaratan utama peserta didik, identifikasi dan verifikasi tugas jabatan serta analisis tugas jabatan dan pengetahauan tambahan yang dibutuhkan.

Kesesuaian deskripsi tugas dan kompetensi guru PAI di lapangan dengan rumusan tujuan diklat akan menjadikan diklat lebih efektif dan efesien. Menurut Blank (1982:121) pengembangan materi pelatihan tidak akan efektif tanpa adanya rumusan tujuan pelatihan yang jelas dan sesuai dengan kebutuhan peserta didik. Lebih lanjut Blank (1982) menyatakan "without clear 
ISSN: 1829-6750 Inovasi Kurikulum, Februari 2009, Thn. 6. Vol 6 Nomor: 1

objective to tell us where learners are going, it is difficult for us to develop learning activities to help them get there or to asses wheter or not they arrived". Ketidakjelasan dan ketidaksesuaian tujuan akan menimbulkan kesulitan bagi seorang pelatih untuk mengembangkan aktivitas pembelajaran.

Deskripsi tuntutan kebutuhan peningkatan kompetensi guru menunjukkan bahwa diklat tidak hanya menekankan peningkatan pengetahuan bagi guru PAI MTs, melainkan juga melakukan peningkatan pengembangan sikap mental dan keterampilan (skills)) yang berhubungan dengan kompetensi guru. Sementara itu, tujuan diklat secara umum mencakup ketiga hal tersebut, namun aspek pengetahuan lebih menonjol. Ketiga aspek tersebut tampak pada rumusan tujuan kurikulum diklat PAI MTs yaitu, peningkatan pengetahuan, keterampilan, kecerdasan dan wawasan tugas guru PAI MTs serta meningkatkan sikap mental, etika dan moral serta berupaya meningkatkan kepribadian, komitmen, dan sikap keteladanan guru PAl.

\section{Kesesuaian Isi Kurikulum Pelatihan dengan Tuntutan Kebutuhtan Kompetensi Guru}

Isi kurikulum merupakan sejumlah materi atau mata diklat yang akan diberikan kepada peserta diklat agar menguasai kompetensi untuk mencapai tujuan diklat yang telah ditetapkan. Isi kurikulum menjawab pertanyaan yang dikemukakan Tyler (1949) "What educational experiences can be provided that are likely to attain these purposes Taylor mengemukakan bahwa ada dua faktor yang seharusnya ditelaah dalam mengidentifikasi isi kurikulum pelatihan, yaitu pemilihan isi kurikulum dan penentuan sequen isi kurikulum. Pemilihan kedua faktor tersebut melibatkan berbagai aspek yang perlu diperhatikan.

Materi/Mata diklat guru PAI MTs dapat mengakomodasi kebutuhan kompetensi guru di madrasah baik pengetahuan, keterampilan maupun sikapnya. Sejumlah pengetahuan, keterampilan dan sikap yang dibutuhkan guru PAI baik untuk meningkatkan kompetensi guru maupun bantuan untuk memecahkan kesulitan dalam menjalan aktivitasnya menjadi kajian-kajian intens dalam penyelenggaraan diklat guru PAI. 
ISSN: 1829-6750 Inovasi Kurikulum, Februari 2009, Thn. 6. Vol 6 Nomor: 1

Temuan penelitian menunjukkan indikasi yang jelas bahwa pengetahuan dan keterampilan serta sikap yang dibutuhkan dalam peningkatan kompetensi guru PAI belum secara keseluruhan termaktub dalam mata diklat/materi diklat PAl guru yang tercantum dalam kurikulum. Kompetensi tersebut termaktub dalam isi kurikulum dapat berupa mata diklat dan dapat juga berupa sejumlah topik include dalam sebuah mata diklat tertentu. Pada diklat tingkat dasar, tampak kecenderungan materi lebih mengarahkan pada aspek tuntutan pengetahuan saja, sementera peningkatan karakter dan keterampilan tertentu belum tercakup secara maksimal.

3. Kesesuaian Stretegi Pembelajaran dalam Kurikulum Pelatihan dengan Tuntutan Kebutuhan Kompetensi Guru PAI

Pebelajar pada diklat guru PAI MTs adalah pebelajar orang dewasa. Pembelajaran orang dewasa menerapkan konsep andragogi. Konsep ini mulai dikembangkan tahun 1926 oleh Eduard C. Lindeman. Menurut Lindeman (Maalcolm,at.al:tth.) perkembangan peserta didik pada usia dewasa tidak sama dengan usia anak-anak, orang dewasa akan belajar lebih baik ketika mereka merasa dilibatkan secara aktif dalam menentukan apa, bagaimana dan kapan mereka mesti belajar.

Menurut Knowles sebagaimana diuraikan dalam The ASTD Technical and Skills Training Handbook ada beberapa asumsi terhadap orang dewasa, yaitu (1) Orang dewasa memiliki suatu kebutuhan untuk mengetahui mengapa mereka harus belajar; (2) Orang dewasa mempunyai nilai lebih dan berbeda kualitas pengalamannya di banding orang yang muda; (3) Orang dewasa lebih siap menerima informasi;

Orang dewasa masuk ke dalam alam belajar; (5) Orang dewasa termotivasi untuk belajar atas dorongan dari dalam diri (intrinsic) dan dari luar (extrinsic) dirinya.

Walace (Noor, 2001) mengemukakan ada tiga pendekatan model pada pelatihan guru, yaitu: Craft Model, Applied Science dan The experimental (reflektive) model. Craft model adalah " the trainees imitate the expert's technique and follow his instructions and advice", peserta pelatihan menyimak secara 
ISSN: 1829-6750 Inovasi Kurikulum, Februari 2009, Thn. 6. Vol 6 Nomor: 1

seksama teknik-teknik dari para ahli dan mengikuti petunjuk dan saransaran. Model ini sering disebul model tukang karena pelatih dapat menurunkan

keahliannya.

Sementara Applied Science model adalah sebuah model penerapan ilmu pengetahuan di mana model ini mengharapkan para peserta diklat untuk mempelajari temuantemuan ilmiah berdasarkan hasil penelitian dalam disiplin ilmu yang berkaitan dengan kependidikan, linguistik, terapan, psikologi, metodologi, dan teori untuk diterapkan di dalam kelas.

Walace (1991) mengemukakan bahwa ada dua sumber pengetahuan, yaitu pengetahuan yang diterima dan diperoleh melalui belajar baik secara formal maupun informal (received knowledge) dan pengetahuan yang diperoleh melalui pengalaman (Experiential knowledge). Kedua sumber pengetahuan tersebut merupakan kunci bagi pengembangan profesionalisme. Model ini berasumsi bahwa masing-masing peserta diklat membawa pengetahuan dan pengalaman ke tempat diklat. Kemudian, pengetahuan dan pengalaman tersebut digunakan dalam alur proses mengajar dan mengingat kembali pelaksanan mengajar tersebut. Efektivitas diklat tergantung pada bagaimana peserta diklat mengkaitkan ingatan pengalaman dan praktek mengajar yang mereka lakukan. Sementara refleksi pengalaman guru adalah untuk menjamin proses dari berbagai input, terlepas dari mana asal input sehingga pengetahuan tersebut menjadi sangat bermanfaat.

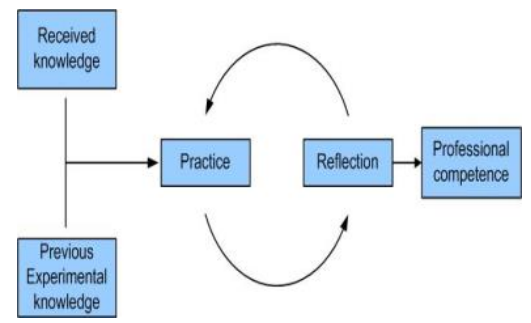

Gambar 2. Reflective Model Wallace (Noor, 2001).

Model yang dikemukakan di atas merupakan salah satu alternatif yang ditawarkan dalam dokumen kurikulum diklat guru PAI MTs melalui pendekatan eksplorasi pengalaman peserta dan praktek lapangan. Dengan alternatif metode yang beragam memberikan isyarat kuat iklim diklat yang efektif dan efesien sesuai dengan tuntutan peningkatan kompetensi guru PAI.
4. Kesesuaian Evaluasi hasil belajar dalam Kurikulum $\mathrm{Pe}$ - 
ISSN: 1829-6750 Inovasi Kurikulum, Februari 2009, Thn. 6. Vol 6 Nomor: 1

latihan dengan Tuntutan Kebutuhan Kompetensi Guru PAI

Evaluasi merupakan bagian penting dari suatu sistem diklat yang efektif. Diklat yang baik dimulai dengan menganalisis kebutuhan apa yang diperlukan bagi diklat, memproses melalui desain, dan pada tahapan akhir diharapkan dengan sistem kerja yang efektif akan tercipta kualitas yang dikehendaki sesuai dengan tujuan yang ditargetkan. Donald Kirkpatrick dalam Brinkerhaff (The ASTD Tehnical and skills Training Handbook,tth) mengemukan bahwa paling tidak ada empat pertanyaan yang perlu diperhatikan tentang proses diklat, yaitu (1) Apakah peserta menyukai diklat tersebut; (2) Materi apa yang seharusnya dipelajari; (3) Apakah mereka memerlukannya; Apakah pelatihan tersebut mempunyai pengaruh bagi organisasi. Pertanyaan tersebut menegaskan kembali pentingnya program diklat yang relevan dengan kebutuhan peserta. Evaluasi pada desain kurikulum diklat guru PAI memiliki fungsi dan peranan yang sama dengan evaluasi pada umumnya. Evaluasi yang digunakan seharusnya sesuai dengan kompetensi apa yang dinilai. Sementara dalam desain kurikulum diklat guru PAI MTs cenderung mengutamakan desain evaluasi pada pre-test dan post test.. Teknik non tes tercantum tetapi tidak dijelaskan secara detail fungsi bahkan instrumen yang digunakan.

\section{F. Simpulan}

Masalah pokok penelitian ini adalah bagaimana relevansi desain kurikulum pelatihan Balai Diklat PAI Manado dengan kebutuhan kompetensi guru Pendidikan Agama Islam di Madrasah Tsanawiyah. Disimpulkan bahwa secara umum desain kurikulum diklat relevan dengan tuntutan peningkatan kompetensi guru dalam hal peningkatan kompetensi pedagogik dan profesional guru PAI. Sedangkan kompetensi sosial dan kepribadian belum terakomodasi secara maksimal.

\section{Daftar Pustaka}

Azizy, A. Q. (2002). Pendidikan (Agama) Untuk membangun Etika Sosial. Semarang: Aneka IImu

Badan Standar Nasional Pendidikan. (2007). Peraturan Menteri Pendidikan Nasional RI Nomor 16 Tahun 2007 tentang 
ISSN: 1829-6750 Inovasi Kurikulum, Februari 2009, Thn. 6. Vol 6 Nomor: 1

Standar Kualifikasi Akademik dan Kompetensi Guru. Jakarta

Blank, W. (1982). Handbook For Developing Competency-Based Training Programs. New Jersey: Prentice-Hall, Inc., Englewood Cliffs.

Departemen Agama RI. (2007) Desain Program Diklat Berjenjang Tingkat Dasar bagi Guru Madrasah Tsanawiyah di Lingkungan Departemen Agama.Jakarta: Pusdiklat Tenaga Teknis Keagamaan.

\section{(2007) Desain Program}

Diklat Berjenjang Tingkat Lanjutan bagi Guru Madrasah Tsanawiyah di Lingkungan Departemen Agama. Jakarta: Pusdiklat Tenaga Teknis Keagamaan

(2007) Desain Program Diklat Berjenjang Tingkat Dasar bagi Guru Madrasah Tsanawiyah di Lingkungan Departemen Agama. Jakarta: Pusdiklat Tenaga Teknis Keagamaan

(2007) Desain Program Diklat Berjenjang Tingkat Dasar bagi Guru Madrasah Tsanawiyah di Lingkungan Departemen Agama. Jakarta:
Pusdiklat Tenaga Teknis Keagamaan

Hamalik, O. (2006). Implementasi Kurikulum. Bandung: Universitas Pendidikan Indonesia.

Noer. I. H. M. (2001) "Model Pelatihan Guru dalam Menerapkan Kurikulum Bahasa Inggris". Jurnal Pendidikan dan Kebudayaan No. 030 tahun ke7.

Peraturan Pemerintah Nomor: 19 tahun 20005 Tentang Standar Nasional pendidikan

Print, M. (1993). Curriculum development and design. Second Edition. Australia: Allen \& Unwin Pty.

Sudjana, D. (2006) Pendidikan dan Pelatihan dalam Ali, M., Ibrahim, R., Sukmadinata N. S., Sudjana, D., dan Rasjidin, W. (penyunting). IImu dan Aplikasi Pendidikan: Handbook. Bandung: Pedagogiana Press Halaman 1325-1350).

Tyler, R. W. (1949). Basic Principles of Curriculum and Instruction.Cicago \&London: The University of Chicagho Press. 
ISSN: 1829-6750 Inovasi Kurikulum, Februari 2009, Thn. 6. Vol 6 Nomor: 1

Undang-Undang RI Nomor 20

Tahun 2003 tentang Sistem Pendidikan Nasional.

Zais, S. Robert. (1976). Curriculum: Principle and Foundation. New York: Harper \& Row. Publisher. Inc. 